\title{
Socioeconomic Impact of Mining in the Atiwa Forest Reserve of Ghana on Fringe Communities and the Achievement of SDGs: Analysis from the Residents' Perspective
}

\author{
Yaw Okyere Akomaning ${ }^{1, *}$, Petra Hlaváčková ${ }^{1}$, , Samuel Antwi Darkwah $^{2}$, Iva Živělová ${ }^{3}$ and Andrea Sujová ${ }^{1}$ \\ 1 Department of Forest and Wood Products Economics and Policy, Faculty of Forestry and Wood Technology, \\ Mendel University in Brno, 61300 Brno, Czech Republic; petra.hlavackova@mendelu.cz (P.H.); \\ andrea.sujova@mendelu.cz (A.S.) \\ 2 Department of Territorial Studies, Faculty of Regional Development and International Studies, \\ Mendel University in Brno, 61300 Brno, Czech Republic; darkwah@mendelu.cz \\ 3 Department of Regional and Business Economics, Faculty of Regional Development and International \\ Studies, Mendel University in Brno, 61300 Brno, Czech Republic; iva.zivelova@mendelu.cz \\ * Correspondence: xakomani@mendelu.cz or yawakomaning@gmail.com
}

\section{check for}

updates

Citation: Akomaning, Y.O.; Hlaváčková, P.; Darkwah, S.A.;

Živělová, I.; Sujová, A. Socioeconomic Impact of Mining in the Atiwa Forest Reserve of Ghana on Fringe

Communities and the Achievement of SDGs: Analysis from the Residents Perspective. Forests 2021, 12, 1395 https://doi.org/10.3390/f12101395

Academic Editor: Davide M.

Pettenella

Received: 22 August 2021

Accepted: 8 October 2021

Published: 13 October 2021

Publisher's Note: MDPI stays neutral with regard to jurisdictional claims in published maps and institutional affiliations.

Copyright: (c) 2021 by the authors. Licensee MDPI, Basel, Switzerland. This article is an open access article distributed under the terms and conditions of the Creative Commons Attribution (CC BY) license (https:/ / creativecommons.org/licenses/by/ $4.0 /)$.

\begin{abstract}
The Atiwa forest reserve of Ghana sits upon roughly 150 million tons of bauxite. The Government has decided to mine and use the proceeds for national infrastructure development programs. This article examines the impact of mining on the residents' livelihoods and the achievement of the SDGs from the perspective of the residents. A questionnaire was administered to 197 respondents. Per the findings, the residents around the forest reserve do not consent to the proposed mining project. Although they give credit to its possible job creation opportunities, the irreplaceable nature of the forest reserve urges them not to consent to the initiative. They depend on the rivers and streams for their livelihoods, and the affected districts are also among Ghana's major cocoa producers. These farmers depend on these water bodies for irrigation. It is necessary to preserve them in order to sustain the production of these cash crops that make a direct contribution to the country's GDP.
\end{abstract}

Keywords: forest degradation; poverty; sustainable forest management; water pollution

\section{Introduction}

The concept of environmental degradation has many definitions [1,2]. This study considers the definition by Tilman et al. [2], which asserts that environmental degradation is: the weakening of the earth through the exhaustion of resources, for example, air, water, and soil; the decimation of biological systems; territory obliteration; the annihilation of wildlife; contamination; and it also assumes that any environmental disruption or exacerbation is deemed hazardous or damaging, and that environmental degradation has an effective impact on ecological destruction. In an accompanying report, Tilman et al. [2] illustrate the High-Level Panel on Threats, Challenges and Change of the United Nations, which presents environmental degradation as one of the ten hazards officially recommended. The United Nations International Strategy for Disaster Reduction characterizes environmental degradation as "the reduction of the capacity of the environment to meet socioecological objectives and needs" [3] (pp. 1-4). The definition propounded by Tilman et al. tackles various components that are critically looked at in the Sustainable Development Goals (SDGs) of the United Nations. Specifically, the forest sector, as a whole, can be categorized to SDG 15, "Life on Land: Protect, Restore, and Promote Sustainable Use of Terrestrial Ecosystems; Sustainably Manage Forests; Combat Desertification; Halt and Reverse Land Degradation, and Halt Biodiversity Loss" [4] (p. 1). Target 15.1 states that "By 2020, ensure the conservation, restoration and sustainable use of terrestrial and inland freshwater ecosystems and their services, in particular forests, wetlands, mountains and drylands, in line with obligations under international agreements" [4] (p. 1), and Target 15.2 states that 
"By 2020, promote the implementation of sustainable management of all types of forests, halt deforestation, restore degraded forests, and substantially increase afforestation and reforestation globally" [4] (p. 1). SDG 15 is directly related to other SDGs [4-6].

A great deal of environmental concern has been directed towards the rapid pace of deterioration and the depletion of forest resources, particularly in the wet tropics in recent years [7]. While the direct causes of such high global forest destruction are ambiguous and not very well understood [8], it is widely accepted that designing and enforcing a successful forest policy effectively is key to the sustainable management of forests [7]. While the extent of forestry loss is debated, it is commonly accepted that between 1900 and 2000, Ghana lost at least fifty percent of its forest cover $[9,10]$.

A typical example of the socioeconomic drivers that affect deforestation were explored by Giliba et al. [11] in their study on the Bereku Forest in Tanzania. They noted that, in Tanzania, deforestation is affected by factors such as the livelihood practices of the people, the distance from homes to the forest, and proximity to the forest. Farms, educational fields, houses, the construction of new roads, and other factors also have an impact on deforestation. Farmland deforestation is based on the everyday needs of the forest land. Forestation has a positive effect by training and delivering extension programs aimed at protecting the environment. Relatedly, Chakravarty et al. [12] considered the increasing degradation of lands in the world and the study found that, with farming practices raising the demand on lands and controlling the geographical and regional sections of land use, this can be observed. The use of group task forces will conserve forest lands and the creation of a deteriorating global environment needs to be approached with the necessary focus. The international environment has adopted and implemented programs, such as REDD+, with the motive of ensuring that forests are protected [13].

The world has learned that, in order to preserve the environment, the rational usage of natural resources is necessary. The loss that is triggered by the unsustainable rates of environmental use by rural citizens for agricultural production, without consideration for the correct water conservation practices, is an increasing concern [14]. Furthermore, the persistent poverty rate in rural areas lures rural farmers into abandoning the rational management of resources and activities for negative practices at the cost of long-term ecosystem impacts for short-term benefit. The international community is also committed to raising the understanding of the environmental effects of unsustainable agriculture and how poverty, which is the key catalyst for rural society in general, can be minimized [13,14]. Environmental degradation is one of the key reasons why farm production is decreasing and rural hunger continues to rise. Forest destruction, which is widespread in Ethiopia, for instance, has had a devastating effect on the nation's sociocultural and ecological climate. The key factors are: fast population growth; high land loss; erosion; poor vegetative cover; and the unequalled production of crops and livestock. In addition, the deterioration mechanisms affected by man are determined by topography, soil types, and agroecological parameters. Conservation initiatives over the course of history have concentrated primarily on the physical conservation mechanisms to manage soil loss and have less commitment than plant measures to prevent the exploitation and erosion of nutrients. However, land degradation can be avoided by various means, depending on the type and nature of degradation, as is stated by various researchers [15].

In Ghana, several environmental degradation studies have been conducted [16,17]. For instance, Ghana's Ministry of Science and Environment, as cited by Ankomah [18], reported that human activities, notably small-scale mining (Galamsey), influence deforestation in most catchment forest areas in Ghana. The report further stipulated that one of the other devastating factors that affects the forest reserves is farming close to the forest. According to their report, $29 \%$ of the degradation of forest reserves is caused by farming close to it. The harvesting of firewood accounted for $21 \%$, illegal lumbering constituted $18 \%$, and bushfires and others causes cover the remaining $32 \%$. 


\subsection{Problem Statement}

When the Atiwa range was originally designated a Forest Reserve in 1926, it was to protect its value as a watershed source. The forest reserve hosts the Birim, Densu, and Ayensu headwaters and their affluent rivers, which are important sources of water for the surrounding communities, including the capital of Ghana, Accra. Not only that, streams, such as Awusu, Kokoben, Obiri ne Obeng, Abudwusu, and others, which are highly depended upon by the people of Atiwa West district, also have their headwaters in the forest reserve. As the years passed, people began to recognize other values of the forest as well. More than 100 species that live in the forest are globally threatened, and more than 227 species of bird call Atiwa home $[19,20]$.

However, for some, the value of Atiwa is not the forest itself, but the minerals that lie beneath its soil. The forest reserve is situated on top of about 150 million tons of bauxite deposit, which is a precious mineral used for aluminum processing. The Government of Ghana intends to mine the bauxite in the Atiwa Range Forest Reserve as part of a national infrastructure development program. The bauxite deposit will be used as a mortgage to the Chinese to fund the country's development drive [21].

Several organizations, such as Rocha Ghana, Friends of Earth Ghana, the Ghana Wildlife Society (BirdLife Partner), the West African Primate Conservation Action, and a number of specialist and state agencies oppose the initiative of mining in the reserve. This is because, in order to mine the Atiwa Range Forest Reserve, the entire forest would have to be removed. While this forest was not seen as irreplaceable, it will be almost impossible to restore the forest after bauxite mining because the soil is very devastated throughout the operation [22]. The Ghanaian government is adamant that they will establish a devastating bauxite mine in the Atiwa Forest [19], despite intense resistance from local and international conservation organizations. This is a globally recognized and important ecosystem that serves as a home to exceptional biodiversity and provides water to five million residents (as mentioned earlier).

The uniqueness of this study is that it seeks to fill in a missing gap with regard to analyzing the situation from the perspective of the residents of the fringe communities of the forest reserve. Of all the analyses conducted, as well as the reports and papers written about the intended mining activities in the forest reserve, none present any views from the perspective of the people who will be directly affected by the project. This study further investigates how mining in the forest reserve may impact the nation's achievement of the SDGs.

Therefore, the main objectives of the study are:

1. To assess the awareness level of the proposed mining in the Atiwa Forest Reserve.

2. To assess the socioeconomic impact of mining in the Atiwa Forest Reserve on the residents of fringe communities.

3. To analyze the impact of mining in forest reserves on the achievement of the Sustainable Development Goals (SDGs).

The research questions are:

1. Are the residents aware of the planned mining of the Atiwa Forest Reserve?

2. How would the mining in the forest reserve affect the socioeconomic development of the residents of fringe communities?

3. How would mining in forest reserves affect the achievement of SDGs?

The study will be useful to the policymakers of the districts that will be affected by the mine development. It will be useful to the District Chief Executives and Regional Ministers, as well as to government agencies, such as the Environmental Protection Agency, the Forestry Commission, and the Minerals commission, when it comes to setting down policies for land use, mining, hunting, etc. NGO's that are interested in the issue of the forest reserve can also use the research findings in their references. 


\subsection{The Atiwa Forest Reserve}

The Atiwa Forest Reserve is found in the eastern region of Ghana. It is considered the largest rainforest in West Africa and serves as a habitat for numerous wild animals. The forest is located close to Accra, the capital city of Ghana, and is "the jewel in the crown" of Ghana's named reserves [23,24]. It is characterized by clear running streams, tropical mountain forests, and it has unique and rare plants and animals that are not found anywhere else in Africa. It is also lush in nature and has a unique arrangement, known as the Atiwa Dotted Border, that attracts butterflies. This attribute of the reserve is incomparable to other forests in the world [23]. Those who live around the forest depend on the forest for food, medicine, clothing, and tools. The forest also prevents drought and flooding because of its forest cover [24]. Water flowing from the Atiwa Forest supplies drinking water to about five million people, including the capital of Ghana, Accra. The benefits derived from the Atiwa Forest Reserve are grouped into four categories: regulatory, cultural and amenity services, provisioning, and habitat. Provisioning services are those tangible materials the local people derive from the forest, such as food (snails, mushrooms, bush meat, honey, and fruits), water, and raw materials, such as timber, rattans, fuelwood, canes etc. [23]. The Atiwa Forest Reserve hosts plant species, such as Odum (Milicia execlsa (Welw.) C.C. Berg), Mahogany (Khaya ivorensis (A. Chev), Wawa (Triplochiton scleroxylon (K.Schum.), and Sapele (Entandrophragma cylindricum (H. Harms), among others. The forest reserve has attracted global attention leading to scientists, such as A Rocha scientists, discovering Cercocebus lunulatus (J. B. Audebert), which is a rare terrestrial monkey in the Atiwa Forest Reserve. These scientists used an infrared camera trap to detect Cercocebus Lunulatus, known as the white-naped mangabey, threatened around the world [19,25]. Atiwa, where the forest is located, is blessed with many minerals, forest products, and water bodies. The mineral resources located at Atiwa include gold, diamond, kaolin, and bauxite. The deposits of gold and bauxite are extracted from the Birim river basin, and towns such as Agyapoma, Abreponso, Kibi, Asikam, Enyiresi, Abekoase and Kwabeng. Kaolin is found in the Atiwa Ranges and manganese is found in Asamama and Apapam. The forest itself is found at Atiwa, covering about 158 square miles, and it has 25 square miles at Apedwa where timber is extracted. The presence of streams and rivers provide the opportunity for fishing and irrigation activities [20].

Figure 1 is a pictorial representation of the map of the Atiwa Forest Reserve with some major water bodies and major fringe communities.

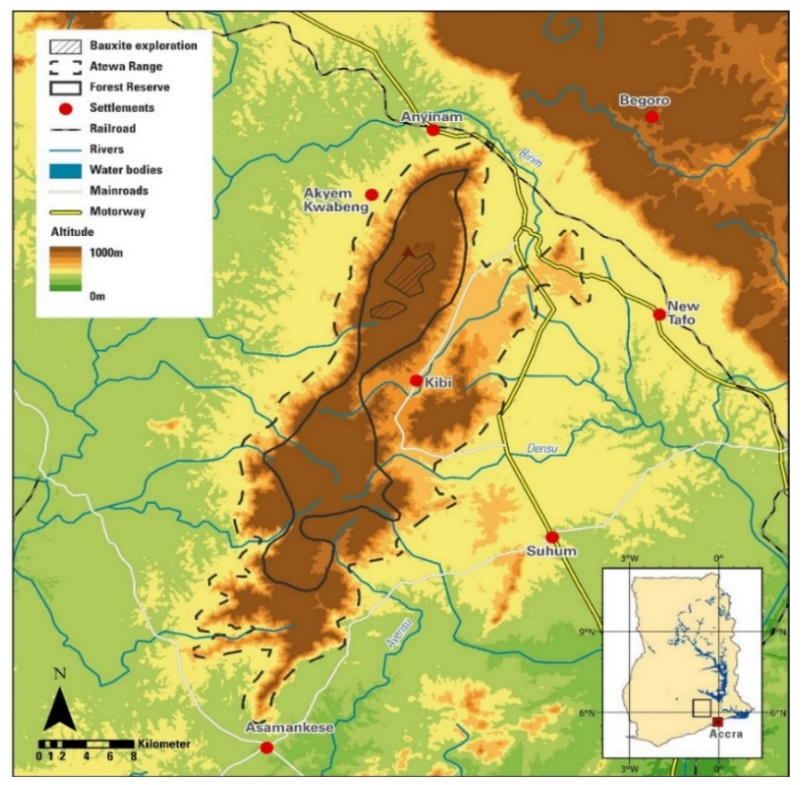

Figure 1. Map of the Atiwa Forest Reserve (study area). Source: A Rocha Ghana [26]. 


\section{Materials and Methods}

The epistemological philosophy of this research is objectivism. Therefore, to achieve the set objectives, the researchers resorted mainly to primary data. Although secondary data is used, the analysis made, and the conclusions drawn, are based on the results of the primary data. The study population consisted of all communities within ten kilometers of the areas in the Atiwa Forest Reserve. The study sample size was calculated using the formula propounded by Krejcie and Morgan [27]. To select the respondents, the cluster sampling method was used. The main tool for collecting the primary data was a structured questionnaire (S1-Questionnaire on Bauxite Mining in The Atiwa Forest Reserve in the Supplementary Materials). The data obtained for different communities were compiled and analyzed using Microsoft Excel (version 2106). Simple descriptive statistics, such as graphs and tables, are used to present the research findings.

To determine the sample size, a proportion of fifty percent was used, for the purpose of this study, as the prevalence of compliance is not known. We also used 0.05 as the degree of accuracy and a 95\% confidence level. The sample size was calculated based on these values:

$$
N=\frac{z^{2} p q}{d^{2}}
$$

Source: Krejcie and Morgan [27]

where;

$N=$ the desired sample size

$z=$ the normal standard deviation usually set at 1.96

$p=$ the proportion estimated to have a specific characteristic in the target population $=7$ percent $=0.07$

$q=1.0-p$

$d=$ degree of accuracy desired, which is set at 0.05

Therefore,

$$
N=\frac{1.96^{2} \times 0.07(1-0.07)}{(0.05)^{2}}=100
$$

Even though 100 respondents were required, a total of 197 randomly selected respondents were involved in answering 17 closed and open-ended questions to ensure maximum participation by the people living in the communities that will be directly affected by the mining project. Precisely, the major towns, Kwabeng (in Atiwa West district), and Kibi (in East Akyem municipality), were the hubs of all the respondents. The respondents were made up of individuals who were 18 years of age or above. To gather these data, the authors employed 10 university students who made sure that all COVID-19 protocols were in place during the collection of the primary data from the study area. Altogether, it took the students about six weeks (8 January 2021-21 February 2021) to collect the data. To achieve the third objective of the study, the authors relied on the results for the first and second objectives. The answers provided by the respondents helped the authors to determine which areas of the Sustainable Development Goals will be affected.

\section{Results and Discussion}

\subsection{Sociodemographic Characteristics of Respondents}

The sociodemographic characteristics of the respondents are presented in Table 1 . The survey shows that the number of male respondents was just three percent predominant over the number of female respondents. 
Table 1. Sociodemographic characteristics of respondents.

\begin{tabular}{|c|c|c|}
\hline Demographic & Frequency & Percentage \\
\hline \multicolumn{3}{|c|}{ Sex } \\
\hline Male & 99 & 50 \\
\hline Female & 93 & 47 \\
\hline Non-response & 5 & 3 \\
\hline \multicolumn{3}{|c|}{ Age } \\
\hline $18-25$ & 13 & 7 \\
\hline $26-29$ & 19 & 10 \\
\hline $30-39$ & 27 & 14 \\
\hline $40-49$ & 43 & 22 \\
\hline $50-59$ & 45 & 23 \\
\hline $60+$ & 48 & 24 \\
\hline Non-response & 2 & 1 \\
\hline \multicolumn{3}{|c|}{ Educational background } \\
\hline No formal education & 41 & 21 \\
\hline No formal education but can read and write & 31 & 16 \\
\hline Basic (Primary, Junior High, Middle School) & 50 & 25 \\
\hline Secondary (Senior High, Technical, Vocational) & 43 & 22 \\
\hline Tertiary education & 30 & 15 \\
\hline No response & 2 & 1 \\
\hline \multicolumn{3}{|c|}{ Occupation } \\
\hline Student & 15 & 8 \\
\hline Farmer & 129 & 65 \\
\hline Teacher & 13 & 7 \\
\hline Civil/public servant & 7 & 4 \\
\hline Trader/businessman & 25 & 13 \\
\hline Artisan & 3 & 2 \\
\hline Unspecified/Unemployed & 5 & 3 \\
\hline
\end{tabular}

Source: Field survey, 2021.

Second, the research indicates that the bulk of respondents were between the ages of 30-60+ years old, suggesting that they were quite mature. Moving on, on the basis of the survey results, the people taking the survey appear to have enough of an educational background to be competent at the work in which they are engaged. Additionally, the results indicate that the majority of respondents were farmers, whom we assumed would be concerned about news of environmental degradation.

\subsection{Awareness Level of the Proposed Mining}

To commence with the data collection, it was deemed necessary to determine whether the respondents were aware, or had any knowledge, about the subject matter. Out of the 197 respondents, $98 \%$ stated that they were aware of the proposed mining of the Atiwa Forest Reserve for bauxite, while the remaining $2 \%$ stated that they were not aware. To determine the source of information, as presented in Figure 2, a majority, i.e., about $46 \%$ of the respondents stated that they heard about this issue on the radio. A total of $35 \%$ indicated that they heard about the proposed mining from other people (through conversation), $8 \%$ affirmed television as their source of information, whereas social media, newspapers, and community information centers had $4 \%, 3 \%$, and $2 \%$, respectively. The remaining $2 \%$ did not provide any answers. This, in a nutshell, gives a clear overview of the fact that the proposed mining of the Atiwa Forest Reserve is no secret to the people living in the fringe and that, not only has it caught the attention of international bodies, but the locals as well. This brings to light the essence of the forest reserve to various stakeholders. 


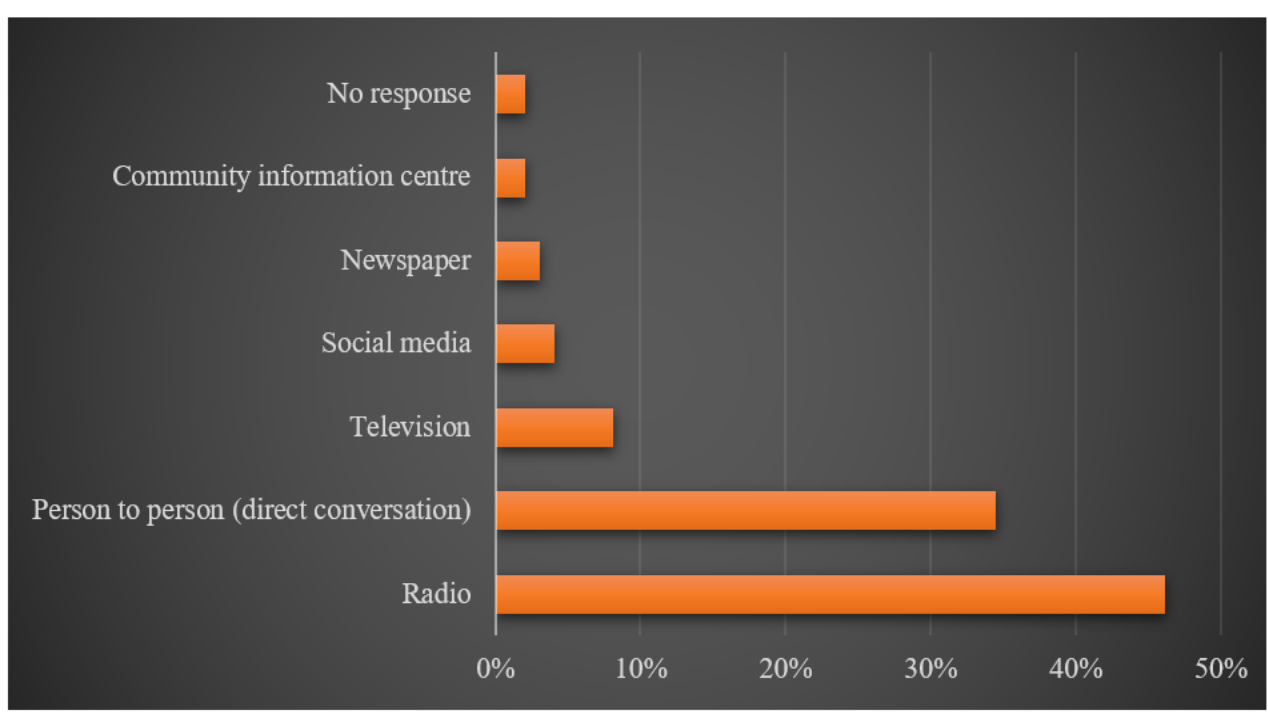

Figure 2. Source of information of respondents on proposed mining of the forest reserve. Source: Field survey, 2021.

\subsection{Socioeconomic Impacts of Mining in the Forest Reserve on Livelihoods}

In this section, questions were posed with the aim of knowing how the mining activity will affect the livelihoods of the people living in the fringe communities of the Atiwa Forest Reserve.

Knowing the level of impact of the proposed mining prompted the need to, first and foremost, identify the level of dependency on the forest reserve for livelihoods. To determine the dependency level of the people on the forest reserve for their livelihoods, $97 \%$ of the 197 respondents indicated that they depend directly on the forest, whereas the remaining 3\% stated that they do not depend directly on the forest for their livelihoods. As to what they depend on the forest for, $78 \%$ stated that they depend directly on the forest reserve for water, $8 \%$ said they depend on the forest for medicine (herbal), $5 \%$ indicated that they depend on the forest for food, $4 \%$ for timberwood, another $4 \%$ stated that they depend on the forest for other things, such as fuelwood, and the remaining $1 \%$ gave no response. This gives an indication that approximately three-quarters of the people living in the fringe communities rely on the forest for water (see Table 2). With various studies, such as Akomaning [13], giving almost a 100\% reliance on the forest for water, this study specifically attempts to identify the main source of water for the communities. As presented in Table 2, about $51 \%$ of the respondents specified that they use pipe-borne water for daily activities and consumption, 37\% stated that their sources of drinking water are direct from rivers and streams, $9 \%$ indicated that they get their drinking water from wells and boreholes, $1 \%$ depend on rainwater, and the remaining $2 \%$ gave no response. The residents mainly depend on the forest for tangible materials, such as food (snails, mushrooms, bush meat, honey, and fruits), water, and raw materials, such as timber, rattan, fuelwood, canes, etc. $[16,23]$. The main sources of drinking water for the residents are pipe-borne water and rivers and streams that have their headwaters in the forest reserve. Pipe-borne water is supplied by the Government of Ghana through Ghana Water Company Limited. According to Akomaning [13], pipe-borne water in the study areas is taken from the streams and rivers that flow from the forest reserve to the treatment plants that are usually stationed a few meters away from the river or the stream. It is, therefore, not wrong to state that about $90 \%$ of the residents depend on the rivers and streams that flow from the forest reserve for drinking, and this implies that these people will have to resort to other sources if the bauxite is mined in the forest. 
Table 2. Products and derivatives from the forest reserve.

\begin{tabular}{ccc}
\hline What Do You Mainly Depend on the Forest for? & Frequency & Percentage \\
\hline Food (plant and animal) & 10 & 5 \\
Water & 156 & 78 \\
Wood & 7 & 4 \\
Medicine & 15 & 8 \\
Other & 7 & 4 \\
No response & 2 & 1 \\
Total & 197 & 100 \\
& What is your source of drinking water? & \\
\hline Pipe-borne water & 102 & 51 \\
Well/borehole & 17 & 37 \\
Rivers/Streams & 74 & 1 \\
Rainwater & 1 & 2 \\
No response & 3 & 100 \\
Total & 197 & 37 \\
\hline
\end{tabular}

Source: Field survey, 2021.

Impact of the Proposed Mining on Livelihoods of the People

Identifying whether the people consider mining in the forest reserve to have a direct impact on their livelihoods was very important for the study. As presented in Table 3, out of the 197 respondents, 187 (representing 95\%) stated that mining in the Atiwa Forest Reserve will have a direct impact on their livelihoods, 8 respondents (representing $4 \%$ ) mentioned that mining in the forest will not have any direct impact on their livelihood, and the remaining $1 \%$ of the respondents did not respond to the question. As further presented in Table 3, out of the 187 people who stated that mining in the forest reserve will have a direct impact on their livelihoods, 61 respondents, representing $33 \%$, stated that they foresee a positive impact, 123 respondents (representing 66\%) stated that they foresee a negative impact, and the remaining $2 \%$ provided no response to the question.

Table 3. Direct impact of mining in the forest reserve on livelihoods of the people.

\begin{tabular}{ccc}
\hline $\begin{array}{c}\text { Do You Think Mining in the Forest } \\
\text { Reserve Will Have a Direct Impact on } \\
\text { Your Livelihood? }\end{array}$ & Frequency & Percentage \\
\hline Yes & 187 & 95 \\
No & 8 & 4 \\
No response & 2 & 1 \\
Total & 197 & 100 \\
\hline & Positive or Negative impact & 33 \\
\hline Positive & 61 & 66 \\
Negative & 123 & 2 \\
No response & 3 & 100 \\
Total & 187 &
\end{tabular}

Source: Field survey, 2021.

In identifying how mining in the forest reserve is going to benefit or affect the people, out of the 61 people who indicated in Table 3 that they anticipate a positive impact on their livelihood, all of them mentioned that more jobs will be created as a result of the mining. This shows that almost all recognize the creation of jobs from the mining development, and one-third anticipate a positive benefit. Meanwhile, out of the 123 people who indicated in Table 3 that they anticipate a negative impact on their livelihood, 71 respondents (representing 58\%) mentioned that mining in the forest reserve will cause unemployment, since most of them are subsistent farmers and rely on rivers and streams flowing from the forest for irrigation. About $23 \%$ of the respondents stated that the mining could lead 
to famine, $14 \%$ anticipate drought, and the remaining $6 \%$ indicated that crime might be higher because of the presence of foreigners (see Table 4).

Table 4. Positive and negative impacts of mining in the forest reserve on livelihoods.

\begin{tabular}{ccc}
\hline Benefit of the Mining & Frequency & Percentage \\
\hline Employment & 61 & 100 \\
\hline Unemployment & Negative impact & \\
Drought & 71 & 58 \\
Famine & 17 & 14 \\
Crimes & 28 & 23 \\
Total & 7 & 6 \\
\hline
\end{tabular}

Source: Field survey, 2021.

From the results, it was identified that the majority of people anticipate that there will be negative impacts from the intended mining project on their livelihood. Even though some of the residents look forward to being employed on the project, the majority indicated that there is the high possibility of unemployment, famine, drought, and crime. Since most of the people are small-scale farmers, they depend on their environment for farming, with specific reference to water for agricultural purposes, such as irrigation. Farmers are demotivated when there are persistent low yields, of which the lack of irrigation is a paramount cause. As earlier indicated, Ghana employs more than $40 \%$ of the population in agriculture, but average agricultural production continues to decline [28]. It is therefore anticipated that most of the people may lose interest in farming, thereby becoming primarily unemployed. The inability of farmers to provide adequate food can lead to famine and food insecurity [29], and the anticipated drought is in relation to the destruction of rivers and streams that flow from the forest. The residents expressed their fear of an increase in crime in the area, which is attributed to the anticipation of high migration and population increase in the mining communities (see Figure 3 for a diagrammatic illustration). Historically, according to Hilson [30], major growth in transport infrastructure, in rail- and roadways, as well as banking, healthcare, and education, in and around the resource-rich areas of Western Ashanti and, to some degree, the eastern and central regions, is being fueled by the relative achievements of exploitation and development within the mining sector under the British colonial administration. The demand for jobs in the mining industry has greatly outstripped supply in historically agricultural industries. It is common knowledge that indigenous or tribal employees were either reluctant, or unable, to satisfy labor standards in certain situations. For this reason, many organizations tend to look for labor outside the vicinity of the industry and, not only that, but also people (both skilled and unskilled) are attracted to these industrial areas in order to make ends meet. The influx of both skilled and unskilled people means an increase in population. As stated by Alvarez-Diaz [23], there is a positive relationship between population growth rate and the crime rate of a vicinity. Many people in mining communities who are not engaged in mining activities often rely on illegal mining, on or near the large-scale mining concessions, a circumstance that often leads to conflict between the parties [31].

\section{Mining $\longrightarrow$ Migration $\longrightarrow$ Population increase} High crime rate

Figure 3. A diagram illustrating the connection between mining and high crime rates.

In determining whether or not they support the proposed mining of the forest reserve from a general point of view, as displayed in Figure 4, about 51 respondents, representing 26\%, indicated that they support the proposed mining in the forest reserve, whereas the majority of the respondents, i.e., 142 people, representing $72 \%$, stated that they do not support it. The remaining $2 \%$ gave no response. From a general point of view, as presented in Table 5 , the 
respondents were given the opportunity to provide one or more reasons why they do or do not support the proposed mining of the forest reserve. Out of the 51 respondents who support the proposed mining, 46 indicated that the mining activities will lead to the creation of jobs. About 7 respondents out of the 51 stated that the government will be attentive to the needs of the people in the affected areas, and 41 respondents mentioned infrastructural development as one of the reasons for supporting the proposed mining. High income was presented by 23 respondents as one of the reasons. However, 2 out of the 51 respondents who stated that they support the proposal did not give any reasons. It was identified that the 49 respondents, out of the 51 who mentioned that they are in favor of the proposed mining, gave at least two reasons to support their opinion.

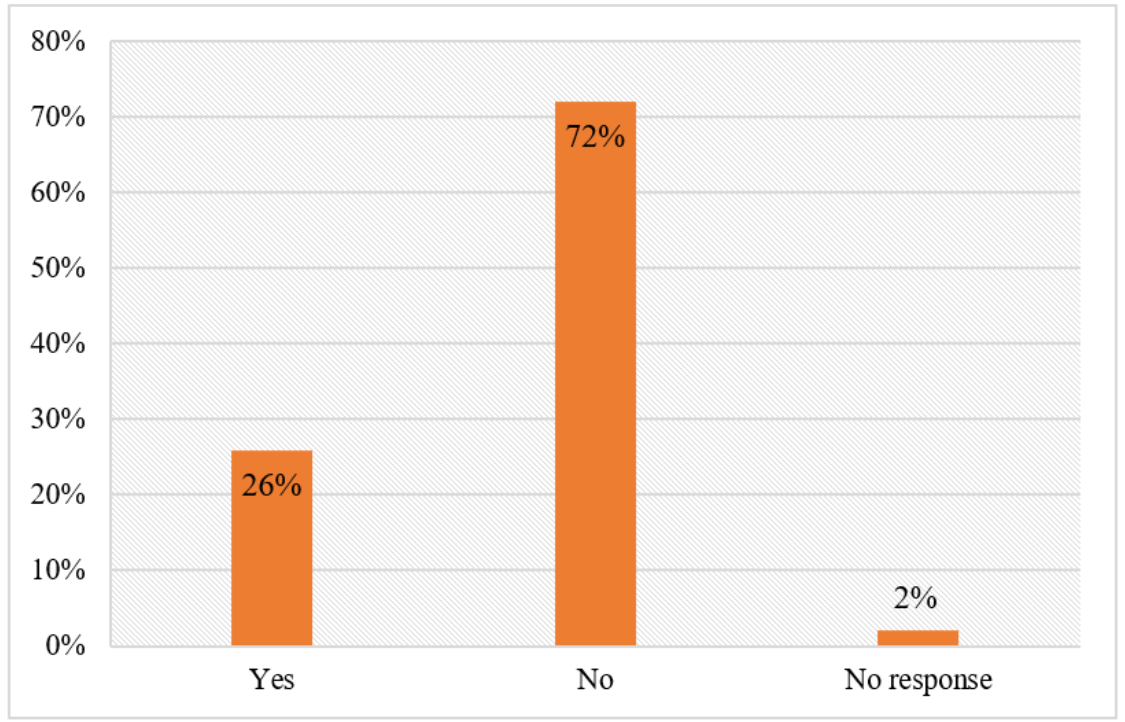

Figure 4. Support for the proposed mining of the forest reserve. Source: Field survey, 2021.

Table 5. Reasons for supporting the proposed mining of the forest reserve.

\begin{tabular}{ccc}
\hline Reasons for Supporting & Frequency out of $\mathbf{5 1}$ for Each Reason & Percentage \\
\hline Job avenue & 46 & 90 \\
Government attention & 7 & 14 \\
Infrastructural development & 41 & 80 \\
High income & 23 & 45 \\
No response & 2 & 4 \\
\hline
\end{tabular}

Source: Field survey, 2021.

Generally, just a small fraction of the population supports the intended project of the government on the notion that the project will not only bring about mining-related job opportunities but will also create avenues for businesses and other economic activities, which will, in turn, generate higher income for the people, and the country at large. As indicated by Aberman and Lal [28], rural households are mostly earning incomes from agriculture in most of sub-Saharan Africa, and the rapid growth of the rural population forces governments to create jobs for the youth. Agriculture in Ghana employs over $40 \%$ of the entire population, but the overall agricultural production remains below expectations, and this is a major problem for the rural livelihoods of people who want to earn higher revenues. This is one of the reasons why those who are in support of mining look forward to switching to other jobs, rather than being subsistence farmers with low income. They are also of the view that the project will lead to the government paying attention to the social needs of the people and will, in the long run, lead to infrastructural development.

Contrary to the above, in Table 6, about 142 respondents indicate that they do not support the proposed mining of the forest reserve. It was also observed that all of the 142 respondents gave at least two reasons to support their decision. Out of the 142 respondents, 121 mentioned 
the impact it will have on agriculture and food production as well as fishing, as one of their reasons. About 139 mentioned the destruction of water bodies, while 19 stated the destruction of cultural heritage as one of the reasons. About 97 of the respondents also indicated the extinction of rare species as a reason, with 27 stating that the forest possesses an existential meaning to them and that they will, therefore, not support its destruction.

Table 6. Reasons for not supporting the proposed mining of the forest reserve.

\begin{tabular}{ccc}
\hline Reasons for Not Supporting & Frequency out of 142 for Each Reason & Percentage \\
\hline Impact on agriculture & 121 & 85 \\
Destruction of river bodies & 139 & 98 \\
Destruction of cultural heritage & 19 & 13 \\
Destruction of biodiversity & 69 & 49 \\
Extinction of rare species & 97 & 68 \\
Existential meaning & 27 & 19 \\
\hline
\end{tabular}

Source: Field survey, 2021.

The results indicate that the majority of respondents, if it is within their power, will not support mining development in the reserve. The respondents are aware of the negative impacts on agriculture, river bodies, and biodiversity, including rare and endangered plant and animal species that can only be found in Atiwa. Apart from the fact that over five million people depend on the rivers and streams from the forest for consumption and farming, and that the mining activities will destroy these waterbodies, the residents believe that reduction in forest cover will have a negative impact on agricultural output $[13,21]$. The Atiwa Forest Reserve, according to the people, has an existential meaning and it is part of their cultural heritage. Therefore, mining it means taking away a precious piece of their cultural opulence and so, therefore, accept as true that there are other means of utilizing the economic potential of the forest reserve other than destroying it. Nyame et al. [29] support these claims by stating that, in many of the agricultural communities in large-scale mining zones, there is low harvesting of crops, poor extension services, decreased soil fertility, inconsistent rainfall patterns, and increased rural-urban drift for the youth. Extremely long gestation periods for many agrarian products, such as oil palm and cocoa, as well as the undeveloped characteristics of local markets, make agriculture unattractive to many people, especially the youth. In addition, socioeconomic reforms, triggered by the presence of large-scale mining and the scarcity of jobs on sites, raise the chances of many indigenous people migrating from remote mineral-rich areas to pursue better employment elsewhere.

\subsection{Impact of the Proposed Bauxite Mining on Achieving Sustainable Development Goals}

As mentioned earlier, the forest sector can be categorized to SDG 15, "Life on Land: Protect, Restore, and Promote Sustainable Use of Terrestrial Ecosystems; Sustainably Manage Forests; Combat Desertification; Halt and Reverse Land Degradation, and Halt Biodiversity Loss". Target 15.1 states that, "By 2020, ensure the conservation, restoration and sustainable use of terrestrial and inland freshwater ecosystems and their services, in particular forests, wetlands, mountains and drylands, in line with obligations under international agreements", and Target 15.2 states that, "By 2020, promote the implementation of sustainable management of all types of forests, halt deforestation, restore degraded forests, and substantially increase afforestation and reforestation globally" [4]. SDG 15 is directly related to other SDGs [4-6,32], and the nature and characteristics of the Atiwa forest reserve makes it crucial in the sphere of sustainable development. The 2020 targets to prevent the loss of biodiversity are falling short across the globe, with over 31,000 species under the threat of extinction $[4,33]$.

It is assumed from the findings that mining in the forest reserve will have a huge impact on both environmentally centered and human-centered SDGs. It is evident from the results that seven goals will be directly affected if the proposed mining project takes place: Goal 1: No poverty; Goal 2: Zero hunger; Goal 3: Good health and wellbeing; Goal 6: Clean water and sanitation; Goal 13: Climate action; Goal 14: Life underwater; 
and Goal 15: Life on land (see Figure 5). Deforestation due to human activity and climate change presents significant threats to sustainable development, impacting the lives and livelihoods of millions of people. Forests play a crucial role in the fight against climate change in order to preserve life on the planet. The ecosystems of various species depend on the health and existence of the forest reserve. Destroying the forest and its water bodies means the destruction of the very foundations of the economy, livelihoods, food security, health, and quality of life across the district, region, and nationwide [33].

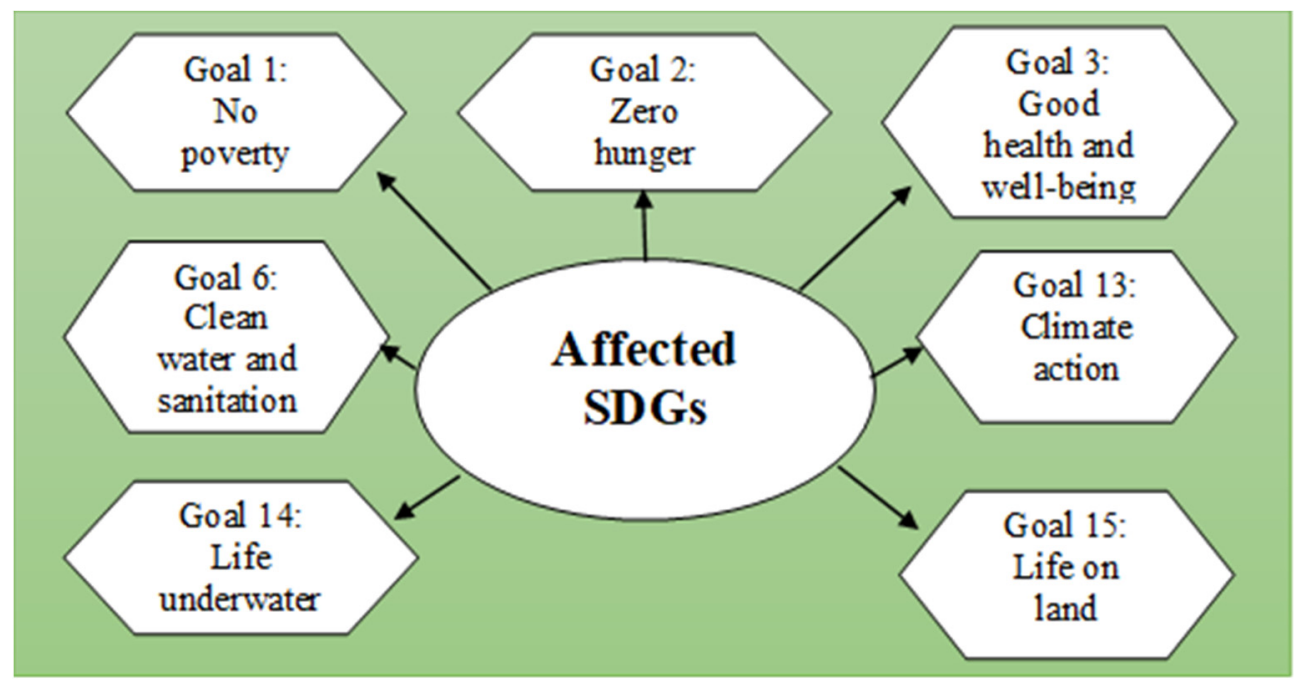

Figure 5. SDGs that are likely to be directly affected by mining in the Atiwa Forest Reserve.

Forests are frequently used as a basis for sustainable development and, as such, they must be thoroughly included in SDG decision-making processes. The link between poverty reduction and forests varies by region, decade, forest transition stage, and market access level. Policies aimed at reducing vulnerability can encourage ecosystem-based adaptation, which includes the extension of forest cover. As programs have proven, reforesting hillsides and reestablishing mangroves helps to avert natural catastrophes [32,34]. This is consistent with findings that forests serve as a buffer and source of natural insurance, as well as a cornerstone of rural livelihoods [34]. However, if poverty alleviation and national development plans are still centered on infrastructure, it is likely to clash with forest protection and sustainable forest management [32]. In fact, forests may be connected to all of the SDGs, either directly or indirectly. Forests produce plant- and animal-based goods that are vital as meals and medicines, thus contributing to the achievement of the SDGs of eliminating hunger and guaranteeing health and wellbeing. Forest employment may help to provide decent work, and forest-based income can help to eradicate poverty [34], as mentioned earlier, and these earnings can be used to buy food, which helps to ensure food security. Forests also produce clean water and have an impact on hydrological cycles and downstream water supplies, thereby contributing to water and sanitation. Forest biomass may help reduce the world's reliance on fossil fuels for energy, and forests can help with responsible consumption and production by supplying sustainable materials to replace nonrenewable ones. Forests may also contribute to economic development and innovation. Some forest communities are among the most egalitarian in the world in terms of gender and equality, while participatory forest management techniques help to develop inclusive societies and institutions. Forests are critical for carbon storage and climate regulation. Forests also provide essential support services, including nitrogen cycling and crop pollination, which are critical for long-term agricultural productivity. Furthermore, mangroves provide coastal protection, increasing the resilience of coastal communities to climate-related risks. Recreational, spiritual, religious, and other nonmaterial advantages are among the forest-related cultural ecosystem services. These advantages are significant 
for both rural and urban people, since they contribute to learning and physical and mental wellbeing, as well as more resilient and sustainable communities. Furthermore, forests contain the majority of the world's terrestrial biodiversity.

\section{Conclusions}

The findings make it clear that a very paramount group of stakeholders, especially the people living in the fringe communities of the forest reserve, if it is within their power, will not agree to the proposed mining project. Even though they give credit to its possible job creation opportunities, the irreplaceable nature of the forest reserve prompts the people not to consent to its destruction. The people lay emphasis on the importance of the rivers and streams that flow from the forest reserve to the people in the fringe communities, and to the capital of Ghana, Accra, as well. Not only do they drink from them, but they also use them for agricultural purposes. The Atiwa district and the East Akim municipality are among the country's major producers of cocoa, who also rely on these water bodies for agriculture. From the viewpoint of the residents, it is necessary to preserve these water bodies in order to sustain the production of these cash crops that make a direct contribution to the country's gross domestic product (GDP). To consider the full effect of this mining project on the environment, the government can perform a strategic environmental assessment. It is of the view that the people look forward to environmentally sustainable development that would serve the people in the affected area, and the entire Ghanaian population, better.

The unique characteristics of the forest reserve present a lifetime of income-generating potential that may not require government mining. The Atiwa Forest Reserve is home to many rare plant and animal species, such as a Cercocebus Lunulatus, known as the whitenaped mangabey that is threatened around the world, the newly discovered frog species, the Afia Birago puddle frog (Phrynobatrachus afiabirago (C. Ofori-Boateng), the Togo slippery frog, which is considered a close relative of the world's largest frog, the goliath frog, is also known to live only in Atiwa Forest and the Togo-Volta Hills of Ghana. Considering the fact that in the 2020 SDG 15 report, over 31,000 species are under the threat of extinction, and Atiwa is home to many threatened species, it is the recommendation of the authors, and also the suggestion of many stakeholders and some of the people in the fringe communities, that the forest be turned into a national park and groomed towards ecotourism, which will present a win-win for all stakeholders and, thereby, help the country in achieving the Sustainable Development Goals. Forests are frequently used as a basis for sustainable development and, as such, they must be thoroughly included in the SDG decision-making processes. Human-caused deforestation and desertification pose enormous obstacles to sustainable development and have impacted the lives and livelihoods of millions of people. Forests are critical to the survival of life on Earth and play a crucial role in the battle against climate change. Investing in land restoration is also essential for improving livelihoods, decreasing vulnerabilities, and lowering economic risks.

Despite, the major threat posed by COVID-19, the objective of the study to analyze this sensitive issue from the perspective of the residents was achieved. The main limitation of the study is the fact that the analysis is solely from the perspective of the residents and does not consider the perspective of the government or how they plan to achieve the SDGs if the forest is mined. Nevertheless, this paper may be a model of a local people's consciousness, and their desire to preserve invaluable nature rather than opt for easy, short-term development.

Supplementary Materials: The following are available online at https:/ /www.mdpi.com/article/10 $.3390 / \mathrm{f12101395/s1,} \mathrm{S1-Questionnaire} \mathrm{on} \mathrm{Bauxite} \mathrm{Mining} \mathrm{in} \mathrm{The} \mathrm{Atiwa} \mathrm{Forest} \mathrm{Reserve.}$

Author Contributions: Conceptualization, Y.O.A. and S.A.D.; methodology, S.A.D., Y.O.A. and P.H.; software, Y.O.A. and S.A.D.; validation, S.A.D., Y.O.A., I.Ž. and P.H.; formal analysis, Y.O.A. and S.A.D.; investigation, Y.O.A.; resources, Y.O.A. and S.A.D.; data curation, S.A.D., Y.O.A., and P.H.; writing-original draft preparation, Y.O.A.; writing—review and editing, S.A.D., Y.O.A., P.H. and I.Ž.; visualization, Y.O.A.; supervision, S.A.D., P.H., I.Ž. and A.S.; project administration, Y.O.A., 
I.Ž. and P.H.; funding acquisition, I.Ž. and P.H. All authors have read and agreed to the published version of the manuscript.

Funding: This research received no external funding. The APC was funded by the Fund for Open Access publishing of the Mendel University in Brno.

Institutional Review Board Statement: No applicable.

Informed Consent Statement: Informed consent was obtained from all subjects involved in the study.

Data Availability Statement: No applicable.

Conflicts of Interest: The authors declare no conflict of interest.

\section{References}

1. Tilman, D.; Fargione, J.; Wolff, B.; D’Antonio, C.; Dobson, A.; Howarth, R.; Schindler, D.; Schlesinger, W.H.; Simberloff, D.; Swackhamer, D. Forecasting agriculturally driven global environmental change. Science 2001, 292, 281-284. [CrossRef] [PubMed]

2. Chertow, M.R. The IPAT Equation and Its Variants. J. Ind. Ecol. 2000, 4, 13-29. [CrossRef]

3. United Nations Department of Economic and Social Affairs. UN International Strategy for Disaster Reduction (UNISDR). 2008. Available online: https:/ / bit.ly/3o6wUSn (accessed on 17 July 2021).

4. United Nations Department of Economic and Social Affairs. Sustainable Development Goal 15 Life on Land: Protect, Restore, and Promote Sustainable Use of Terrestrial Ecosystems; Sustainably Manage Forests; Combat Desertification; Halt and Reverse Land Deg-radation, and Halt Biodiversity Loss. 2020. Available online: https: / bit.ly /3zbWG9R (accessed on 17 July 2021).

5. Huesemann, M.; Huesemann, J. Techno-Fix: Why Technology Won't Save Us or the Environment; New Society Publishers: Gabriola Island, BC, Canada, 2011; ISBN 0865717044. Available online: https:/ / stanford.io/37SdJCK (accessed on 10 July 2021).

6. MacDonald, G. Water, climate change, and sustainability in the southwest. Proc. Natl. Acad. Sci. USA 2010, 107, $21256-21262$. [CrossRef] [PubMed]

7. Food and Agriculture Organization. Global Forest Resources Assessment 2010; Food and Agriculture Organization of the United Nations: Rome, Italy, 2010; Available online: https:/ / bit.ly/2ZpXIm5 (accessed on 22 June 2021).

8. Hobley, M. Where in the World Is There Pro-Poor Forest Policy and Tenure Reform? Rights and Resources Initiative: Washington, DC, USA, 2007; Available online: https:/ / cutt.ly /MlFBHwr (accessed on 15 June 2021).

9. Agrawal, A. Forests, Governance, and Sustainability: Common Property Theory and its Contributions. Int. J. Commons 2007, 1, 111-136. [CrossRef]

10. Oduro, K.; Foli, E.G.; Mohren, G.M.J.; Dumenu, W.K. Ghana (Part II: Management for sustainable forestry in other tropical countries). In Sustainable Management of Tropical Rainforests—The CELOS Management System; Werger, M.J.A., Ed.; Tropenbos Series; Tropenbos International: Paramaribo, Suriname, 2011; No. 25; pp. 242-254. Available online: https://edepot.wur.nl/196841 (accessed on 2 July 2021).

11. Giliba, A.R.; Boon, K.E.; Kayombo, J.C.; Chirenje, L.I.; Musamba, B.E. The Influence of Socio-economic Factors on Deforestation: A Case Study of the Bereku Forest Reserve in Tanzania. J. Biodivers. 2011, 2, 31-39. [CrossRef]

12. Chakravarty, S.; Ghosh, S.K.; Suresh, C.P.; Dey, A.N.; Shukla, G. Deforestation: Causes, effects and control strategies. Glob. Perspect. Sustain. For. Manag. 2012, 1, 1-26. [CrossRef]

13. Akomaning, Y.O. Effects of Degradation of the Atiwa Forest Reserved on the Socioeconomic Development of the Atiwa District of Ghana. Master's Thesis, Mendel University in Brno, Brno, Czech Republic, 2018.

14. Nwokoro, C.V.; Chima, F.O. Impact of Environmental Degradation on Agricultural Production and Poverty in Rural Nigeria. Am. Int. J. Contemp. Res. 2017, 7, 6-14. Available online: https:/ / bit.ly/3uJ71GZ (accessed on 12 July 2021).

15. Gashaw, T.; Bantider, A.; Hagos, G.S. Land degradation in Ethiopia: Causes, impacts and rehabilitation techniques. J. Environ. Earth Sci. 2014, 4, 98-104.

16. Boateng, D.O. The Impact of Golden Star Wassa Limited (GSWL) Operations on its Catchment Communities. Master's Thesis, Kwame Nkrumah University of Science and Technology, Kumasi, Ghana, 2012. Available online: https://bit.ly/3sCmB7k (accessed on 15 July 2021).

17. Lurimuah, S. The Economic and Environmental Effects of Commercial Charcoal Production in the Upper West Region of Ghana. Master's Thesis, Kwame Nkrumah University of Science and Technology, Kumasi, Ghana, 2011. Available online: https:/ / bit.ly/2Objq7G (accessed on 20 July 2021).

18. Ankomah, F. Impact of Anthropogenic Activities on Changes in Forest Cover, Diversity and Structure in the Bobri and Oboyow Forest Reserves in Ghana. Master's Thesis, Kwame Nkrumah University of Science and Technology, Kumasi, Ghana, 2012. Available online: https:/ / bit.ly/38bp6WP (accessed on 21 July 2021).

19. Birdlife International. Major Manufacturing Companies Oppose Mining in Atewa Forest, Ghana. Available online: https: / / bit.ly /2ZHOrD2 (accessed on 3 February 2021).

20. McCullough, J.; Alonso, E.L.; Naskrecki, P.; Wright, E.H.; Osei-Owusu, Y. An Ecological, Socio-Economic and Conservation Overview of the Atewa Range Forest Reserve, Ghana. Conservation International, Center for Applied Biodiversity Science 2007. Available online: https: / bit.ly/2GP2jW1 (accessed on 18 May 2021). 
21. Ghana Business News (GBN). Reconsider the Decision to Mine in Atiwa Forest-CSOs to Government. 15 March 2019. Available online: https:/ / bit.ly/3qFbMlp (accessed on 6 April 2021).

22. Yoda, A.S.S. "We Have Cut Them All”: Ghana Struggles to Protect Its Last Old-Growth Forests. Mongabay Series: Forest Trackers. 2019. Available online: https:/ / bit.ly/2GVf9C1 (accessed on 10 January 2021).

23. Alvarez-Diaz, M.; D’hombres, B.; Ghisetti, C.; Pontarollo, N.; Dijkstra, L. The Determinants of Population Growth; Publications Office of the European Union: Luxembourg, 2018; ISBN 978-92-79-93404-9. [CrossRef]

24. Addy, G.C. Eco-Fest Foundation at Atewa Range. The Ghanaian Times-Accra. June 2001. Available online: https://bit.ly/ 2MivCmM (accessed on 10 January 2021).

25. Wildlife Extra. Study of Pristine Ghanaian Forest Reveals New, Rare, and Threatened Species. 2007. Available online: https: / / bit.ly/3b1tDNm (accessed on 15 January 2021).

26. A Roacha Ghana. Location of Bauxite Exploration Area in the Atewa Range Forest Reserve, Ghana. 2020. Available online: https:/ / bit.ly/3AaYFNf (accessed on 6 May 2021).

27. Krejcie, R.V.; Morgan, D.W. Determining Sample Size for Research Activities. Educ. Psychol. Meas. 1970, 30, 607-610. [CrossRef]

28. Aberman, N.; Lal, R. Employment, diversifying rural livelihoods, and youth: Lessons for Ghana from the 2019 Global Food Policy Report. Int. Food Policy Res. Inst. 2019. Available online: https://bit.ly/3dkSiO7 (accessed on 12 May 2021).

29. Nyame, F.K.; Grant, J.A.; Yakovleva, N. Perspectives on migration patterns in Ghana's mining industry. Resour. Policy 2009, 34, 6-11, ISSN 0301-4207. [CrossRef]

30. Hilson, G. Harvesting mineral riches: 1000 years of gold mining in Ghana. Resour. Policy 2002, 28, 13-26. [CrossRef]

31. Hilson, G.; Yakovelva, N. Strained relations: A critical analysis of the mining conflict in Prestea, Ghana. Political Geogr. 2007, 26, 98-119. [CrossRef]

32. UNSDG. Sustainable Development Goals. 2021. Available online: https://sdgs.un.org/goals (accessed on 21 July 2021).

33. Mohr, J. A Toolkit for Mapping Relationships among the Sustainable Development Goals (SDGs). 2016. Available online: https: / bit.ly/36MQM2M (accessed on 17 July 2021).

34. Katila, P.; Pierce Colfer, C.J.; de Jong, W.; Galloway, G.; Pacheco, P.; Winkel, G. Sustainable Development Goals: Their Impacts on Forests and People; Cambridge University Press: Cambridge, UK, 2019. [CrossRef] 